\title{
Digital Development of the Economy and its Role in Improving the Competitiveness of Ukraine at the International Level
}

\author{
Akymenko Olena, Petrovska Alina, Zholobetska Maryna, Skrytskyi Dmytro
}

\begin{abstract}
The article explores digital development and determines its role in improving the competitiveness of Ukraine. The definition of the digital economy has been given as an economy where the key factors and means of production are digital data (binary, information, etc.) and network transactions, as well as their use as a resource, which can significantly increase the efficiency and productivity of activities and value for products and services received. It has been outlined the reasons for Ukraine's lag in the implementation of digitalization, namely: political and regulatory environment; low efficiency of Ukrainian legislative bodies, judicial system; problems with protection of intellectual property; low level of introduction of new technologies by business; low impact of IT on the emergence of new business models; outflow of human capital. The principles of digitalization have been analyzed. It has been proved the expediency of choosing the target development scenario by the state: the main motivation of Ukraine is ability of digital technologies to rapid increase in productivity and efficiency of economy and business (which leads to complete transformation of the old system and modernization due to digital technologies); a key strategy is a focus on the internal market; key initiatives are formation of motivation, demand, and digital needs for digital technologies among consumers (business, government, and citizens).
\end{abstract}

Keywords: digitalization, modernization, competitiveness, economy, infrastructure, principles, sustainable growth

\section{INTRODUCTION}

At the current stage of world development, it is difficult to underestimate the role of information in modern society. Digitization of the economy is becoming a priority for the development of most civilized countries. Singapore, UK, New Zealand, the UAE, Estonia, Japan, Israel are leading digital economies that have already set a course for digital development in the spheres of transport, education, electronic equipment, and the latest technologies. Throughout the world, the share of the traditional economy is decreasing and the digital one is growing, providing huge benefits for countries and businesses. This is evidence that overseas economies are undergoing powerful digital and technological modernization.

Ukraine has reached the 64th position among 139 countries of the world by the level of development of

Revised Version Manuscript Received on October 15, 2019.

Akymenko Olena, $\mathrm{PhD}$ in Economics, Associate Professor, Chernihiv National University of Technology, Chernihiv, Ukraine. (Email: elena.akymenko@gmail.com)

Petrovska Alina, Postgraduate, Chernihiv National University of Technology, Chernihiv, Ukraine. (Email: alina777petrovskaya@gmail.com)

Zholobetska Maryna, Postgraduate, Chernihiv National University of Technology, Chernihiv, Ukraine. (Email: zholobetska@ukr.net)

Skrytskyi Dmytro, Postgraduate, Chernihiv National University of Technology, Chernihiv, Ukraine. (Email: skrytko@gmail.com) information and communication technologies, as indicated in the Global Information Technology Report 2016 published by the World Economic Forum [1]. In particular, among the reasons for such positions of Ukraine in the ranking are gap by the components that characterize: political and regulatory environment; low efficiency of Ukrainian legislative bodies, judicial system; problems with protection of intellectual property; low level of introduction of new technologies by business; low impact of IT on the emergence of new business models; outflow of human capital.

We consider it is appropriate to initiate a review of measures to implement appropriate incentives for the digitalization of the economy, public and social spheres, awareness of existing challenges and tools for digital infrastructure development, and the acquisition of digital competencies by citizens.

\section{PROCEDURE FOR PAPER SUBMISSION}

The methodological basis of the article is a set of general scientific and special research methods, among which it is necessary to distinguish system-structural analysis - in specifying and ordering the category "digital economy", dialectical, method of analysis and synthesis - to summarize the principles of digitalization, to study scenarios of digital economy development in Ukraine assessing the criticality and necessity of dramatic changes in the economic context (evolutionary and target).

\section{REVIEW CRITERIA}

The lack of appropriate strategies, initiatives of digitization of the economy and life spheres of society and Ukraine as a whole, slow down the digital transformations of business and sectoral structures of the Ukrainian economy. For this reason, the solution of issues related to use of digital tools and solutions is relevant and timely, despite the scale of scientific achievements that have already been reflected in the papers of leading scientists, including: O.Bilorus, R Buchta, R. Hicks, O. Dzhusov, J. Manika, J. Wetzel, K. Stamenov, S. Gupta, M. Kin, A. Shakh, and Zh. Verdier et al. Therefore, the issues related to the development of the digital economy need in-depth research, given that digital development plays a key role in the socio-economic upliftment, enhancing foreign economic activity and 
improving the competitiveness of our country at the international level.

\section{MATH}

The purpose of the article is to investigate the reasons for the gap of Ukraine with European countries in the development of the digital economy.

\section{RESULT AND DISCUSSION}

The Decree of the Cabinet of Ministers of Ukraine No. 67 dated January 17, 2018 On the Concept of the Development of the Digital Economy and Society of Ukraine for 2018 2020 started the movement of Ukraine towards the development of the digital economy, the economy where the key factors and means of production are digital data (binary, information, etc.) and network transactions, as well as their use as a resource, which can significantly increase the efficiency and productivity of activities and value for products and services received [2, 3].

On July 9, 2018, the 20th EU-Ukraine Summit was held, where participants welcomed the continued willingness of Ukraine for the further approximation of its legislation to the EU legislation according to EU-Ukraine DCFTA, in particular in the digital market [4].

In January 2019, a regular meeting of the Coordination Council was held, the agenda of which included the following topical issues: the Concept and Structure of the draft Law On the Digital Economy of Ukraine; the Digital Infrastructure (Broadband Internet Access); the Concept of Development of Non-cash Payments in Ukraine (the Cashless Economy Program); the Digital Development of the Regions (Smart City Program); the European Union Program - EU4Digital [5]. That is, the adaptation to the digital infrastructure is slow but ongoing.

However, full adaptation to the digital infrastructure requires necessary digital knowledge. Thus, the experts highlight the main driving forces cause the need to develop work skills and digital knowledge in the future, namely: increasing globalization; life extension; job automation; rapid spread of sensors and computing power; means of communication and mass-media; unprecedented reorganization of work due to new technologies and social media that greatly enhance collaboration opportunities [3]. Obviously, the most important condition for the development of any digital market in any country will be the development of digital skills, which are considered to be an initial framework condition for the development of all other priorities in the harmonization of the digital markets of the EU and the Eastern Partnership.

The analysis of the documents on the creation of digital spaces in Europe and the world has allowed the developers of the Digital Agenda of Ukraine 2020 Project to form the basic principles of digitalization of Ukraine, the observance of which will be crucial for the creation, implementation and reaping the benefits of "digital technologies". In this way, the basic principles of digitalization are the following:

1. accessibility that means providing every citizen with equal opportunities for access to services, information, and knowledge provided on the basis of information and communication technologies, through the consolidation of

efforts of politicians, state authorities, business, and the public;

2. focus (digital purpose) includes creating benefits in various aspects of daily life and different spheres of human and country life with the aim of improving the quality of health care, creating new jobs, developing entrepreneurship, agriculture, transport, environmental protection and managing natural resources, enhancing culture, reducing poverty, preventing disasters, etc.;

3. economic growth through the use of digital technologies is achievement of the "digital" transformation of existing sectors of the economy, spheres of activity, their new quality and properties (using not selective informatization, but inclusive "digitalization", which will transform the existing systems and areas into new value).

4. freedom of the press and information (independence, diversity of mass media) means promoting the creation and development of the information society, the media, the "creative" environment, and the "creative" market by defining the main role of creating, disseminating and preserving the content in different languages and formats with proper recognition of the rights of authors, which will promote social, cultural and economic development, strengthen the information society (since freedom to seek, receive, impart and use information for creation, accumulation and dissemination of knowledge is a key factor in the healthy development of information society);

5. openness and cooperation mean orientation towards international, European, regional cooperation in order to integrate Ukraine into the EU, entry into the European and world e-commerce and services market, banking and exchange activities, cooperation and interaction in regional markets because it is globalization is the result of the dissemination of information and communication technologies;

6. standardization implies that the development and use of open, interoperable, non-discriminatory standards are the basic elements in the development and dissemination of digital technologies;

7. security and trust mean that enhancing and building confidence in the security using information and communication technologies (hereinafter, ICT) through the introduction of the national cybersecurity culture (information security, cybersecurity, personal data protection, privacy and rights of ICT users) are prerequisite for the development and security of digitalization);

8. comprehensiveness and systematicity include concentration of the influence of public administration on the development, promotion, implementation of national digital strategies in order to remove barriers to digitization of the country, correction of market mechanisms, support of fair competition, attraction of investments, development of the digital infrastructure and digital economy [6].

Digital transformation is a difficult task for Ukraine, but notwithstanding, it must take place not only in technological direction but also in institutional, economic and industrial ones. Furthermore, digital teams should focus on three key 
functional activities, namely: development of the digital strategy, management of digital activity through their national companies, and transformation of their digital implementation into an operational advantage.

Depending on the assessment of the criticality and the need for dramatic changes in the economic structure, there are most likely two scenarios of the development of the digital economy of Ukraine them - inertial (evolutionary) and targeted (forced) ones.

The implementation of the inertial (evolutionary) scenario implies an inertial continuation of the tendencies of the past. As a result of such a scenario, the Ukrainian economy will be ineffective; labor migration, "brain drain" will continue; and Ukrainian products will lose competition in foreign markets. The steps taken by the state in terms of regulatory support will not be sufficient for GDP growth. Ukraine will remain on the sidelines of civilization.

In case of implementation of the target (forced) scenario, the key strategy of Ukraine should be focused on the internal market and include the following: firstly, ensuring the Rule of Law and removing institutional (legislative, tax, etc.) barriers that hinder the development of the digital and innovative economy; secondly, systematic governmental stimulation of the digitalization of the economic and business sectors; thirdly, initiation by the state of large-scale transformation initiatives and digitization projects.

As a result, the Ukrainian economy will develop, the share of the digital economy will significantly increase (up to $65 \%$ of GDP), an expected nominal GDP of Ukraine will reach \$1 trillion USA in the year 2030E.
The ability of digital technologies to rapidly increase productivity and efficiency of the economy and business is the main motivation of the state to choose the target development scenario for the growth of citizens' incomes, capitalization of business, tax revenues to the budget.

Thus, the digital age is changing the approach to doing business, as well as the requirements for the information technologies used: marketing, sales and service management systems; telephony and messenger; workflow and personnel management systems; accounting systems, etc. Digital technologies, products, and services that are considered innovative trends of the modern socio-economic environment are already in use (Table 1).

The active deployment of high-speed networks depends on government incentives: focusing on creating optimal market conditions, we need to create incentives for powerful expansion in the private equity market. Such key incentives are initiatives to develop sustainable digital needs among the citizens of Ukraine through areas such as education, medicine, tourism, transportation, e-government, "smart-city", etc. After all, the ultimate goal is not just to provide citizens with fixed broadband infrastructure, but to ensure that citizens need it, especially those who are aimed at improving life, comfort, education, business, development, etc. $[6$, c. 32,7, p.6]

Table 1. - Digital technologies as innovative trends of the modern socio-economic environment [7]

\begin{tabular}{|c|c|}
\hline $\begin{array}{l}\text { Type of Product / } \\
\text { Service }\end{array}$ & General Characteristics of Product / Service of the Digital Economy \\
\hline BioTech & $\begin{array}{l}\text { (Greek: bios, "life" and techne, "art, skill") - the use of living organisms and biological processes in } \\
\text { production, agriculture, and medicine using high technology. Biotechnological processes with the use of } \\
\text { microorganisms and enzymes at the current technical level are widely used in the food industry. }\end{array}$ \\
\hline NanoTech & $\begin{array}{l}\text { They are high-tech centers, enterprises engaged in the development, packaging, testing of } \\
\text { microelectronic products, namely semiconductor wafers, silicon crystals, integrated circuits with } \\
\text { high-quality control standards. Nanotechnology is the technology of colloidal systems, which includes } \\
\text { colloidal chemistry, colloidal physics, molecular biology, and all microelectronics. }\end{array}$ \\
\hline RetailTech & $\begin{array}{l}\text { (English: retail, "selling products or services to customers through multiple distribution channels in order } \\
\text { to make a profit" and tech "technology". RetailTech is a technology developed by startups for application } \\
\text { in the commercial field. These technologies include 3D body scanning, consumer tracking with } \\
\text { AI-enabled assistants to help retailers and consumers. (AI (Adobe Illustrator) - a file format developed by } \\
\text { Adobe Systems for storing vector images. Adobe Illustrator uses the .ai extension to store AI files. AI } \\
\text { supports almost all programs related to vector graphics. This format is the best mediator for image } \\
\text { transfer from one program to another one. In spite, it gives way to CorelDRAW in illustrative capacities } \\
\text { (can contain only one page in one file, has a small working field - this parameter is very important for } \\
\text { outdoor advertising - only } 3 \times 3 \text { meters), however, it is the most stable and compatible with PostScript, } \\
\text { which are guided almost all publishing applications). }\end{array}$ \\
\hline FinTech & $\begin{array}{l}\text { Technological projects in the field of financial services, which are considered one of the most promising } \\
\text { (and therefore in demand) directions for startups, despite the complexity of state regulation that they have } \\
\text { to face with, operating in this direction. There are two main types of FinTech based products. The first } \\
\text { type was introduced on the market long ago and provides software and financial services, that is, uses the } \\
\text { B2B model. The second one has been actively evolving recently and is consumer-oriented, that is, } \\
\text { captures the B2C market and seeks to fulfill an extremely ambitious task - to compete with traditional } \\
\text { financial service providers in the fight for the mass client. }\end{array}$ \\
\hline
\end{tabular}




\begin{tabular}{|c|c|}
\hline LegalTech & $\begin{array}{l}\text { Digital technology in the legal field of business, specializing in information and technological services } \\
\text { for professional legal activity, and since the late } 2000 \text { s has been providing consumers with legal services } \\
\text { using information technology. In the latter case, there may be an on-line mediation between the client and } \\
\text { the law firm or the provision of legal self-service tools, which eliminates the need to consult professional } \\
\text { lawyers. In addition, it is possible to talk about the legal tech movement, which aims to revise traditional } \\
\text { views on solving legal issues through the introduction of modern information technology in the field of } \\
\text { legal services. }\end{array}$ \\
\hline InsurTech & $\begin{array}{l}\text { InsurTech (the field of advanced insurance technology) takes a great place in the financial and } \\
\text { technological arena. InsurTech is the introduction of innovative solutions designed to maximize the } \\
\text { effectiveness of new technologies in the insurance market. InsurTech is the connection and } \\
\text { interpenetration of the traditional concept of insurance with the latest technologies similar to the concept } \\
\text { of FinTech. InsurTech makes it possible to change the "rules of the game" for insurers, allowing them to } \\
\text { innovate, keep offerings up-to-date and grow. InsurTech receives funding along with investments in the } \\
\text { FinTech sector. The great potential of InsurTech lies not in giving existing insurance products a digital } \\
\text { form, but in radically changing the product or the process of conclusion of a treaty for its provision in } \\
\text { order to improve customer service. }\end{array}$ \\
\hline GovTech & $\begin{array}{l}\text { GovTech includes all IT products, solutions, developments, and services that help to solve the problems } \\
\text { of the public sector. GovTech solves the following problems: } \\
\text { - participation. Creating platforms for citizen collaboration, e-petitions, crowdsourcing. Enhancing } \\
\text { electronic identification capabilities. These technologies are better known as CivicTech; } \\
\text { - infrastructure (digital sensors, control sensors); } \\
\text { - provision of services in education and health care; } \\
\text { - regulation (solution for valuation of objects, carrying out of checks); } \\
\text { - administration (licensing, management of cloud technologies, and software). }\end{array}$ \\
\hline
\end{tabular}

It is necessary to create such a mechanism, which could help citizens to improve their digital skills. Some government initiatives have already taken place. For example, on September 18, 2019, the Cabinet of Ministers of Ukraine issued the Resolution No. 856 On the Ministry of Digital Transformation, which initiated the creation of a new body, which will be responsible for the formation and implementation of state policy in the field of digitization, open data, national electronic information resources and interoperability, implementation of electronic services, electronic trust services, etc. [10]. The Ministry of Finance will also develop the digital skills of citizens.

Formation and implementation of the state policy in certain areas are the main tasks of the Ministry of Digital Transformation. The current normative act refers to the following spheres:

digitalization, digital development, digital economy, digital innovation, e-governance and e-democracy, development of the information society;

- development of digital skills and digital rights of citizens;

- $\quad$ open data, development of national electronic information resources and interoperability, development of infrastructure of broadband Internet access and telecommunications, e-commerce and business;

- $\quad$ electronic and administrative services;

- electronic trust services and electronic identification;
IT industry development.

The main goals of the Ministry of Digital Transformation are creating 100 public services for citizens and businesses in a digital form, connecting $100 \%$ of cities to adequate mobile communication and the Internet, teaching 6 million Ukrainians basic digital skills, increasing the share of IT in GDP of the country to $10 \%$.

\section{CONCLUSION}

The development of e-governance, the rapid and high-quality provision of citizens with services by means of information technologies is one of the important areas of cooperation between the European Union and Ukraine.It is connected with complex and difficult for understanding technical processes, however, the results greatly simplify everyone's life.

E-government allows registering real estate or business without bureaucratic red tape, getting a passport, applying for childbirth assistance and solving hundreds of other everyday issues. In addition to the benefits for ordinary citizens, the development of digital infrastructure will mean reducing corruption, improving the business climate, creating new jobs (respectively, cessation of migration), reducing Ukraine's economic backwardness from developed countries and further sustainable, innovative and intensive economic growth. 


\section{REFERENCES}

1. The Global Information Technology Report 2016. Innovating in the Digital Economy URL: http://www3.weforum.org/docs/GITR2016/WEF_GITR_ Full_Report.pdf.

2. On the Concept of the Development of the Digital Economy and Society of Ukraine for 2018 - 2020, the Decree of the Cabinet of Ministers of Ukraine No. 67 dated January 17, $2018 \quad$ [Pro kontseptsiiurozvytkutsyfrovoiekonomiky ta suspilstvaUkrainyna $2018-2020$ roku, rozporiadzhenniamKabinetuMinistrivUkrainy № 67 vid 17 sichnia $2018 \mathrm{roku}]$ URL: http://zakon1.rada.gov.ua.

3. 2030E Ukraine 2030E - a country with advanced digital economy[Ukraina 2030E - kraina Z rozvynutoiutsyfrovoiuekonomikoiu]: URL :https://hvylya.net/analytics/economics/ukraina-2030e-kr aina-z-rozvinutoju-cifrovoju-ekonomikoju.html.

4. Problems and prospects of harmonization of the digital market of Ukraine with the EU and the EaP countries : analytical report [Problemy ta perspektyvyharmonizatsiitsyfrovohorynkuUkrainy Z rynkamyYeS ta krainSkhP : analitychnyizvit]: URL : https://cid.center/wp-content/uploads.

5. Digital competencies as a condition for formation of the quality of human capital: analytical note [Tsyfrovikompetentsii yak umovaformuvanniayakostiliudskohokapitalu :analit. zap.] / [V. S. Kuibida, O. M. Petroie, L. I. Fedulova, H. O. Androshchuk]. - Kyiv : NAPA, 2019. - 28 p.

6. Digital Agenda of Ukraine - 2020. Project [TsyfrovaadzhendaUkrainy - 2020. Proekt (Tsyfrovyiporiadokdennyi - 2020)], - HIGH-TECH OFFICE UKRAINE, 2016: URL: https://ucci.org.ua/uploads/files/58e78ee3c3922.pdf.

7. N.M. Kraus, O. P. Holoborodko, K. M. Kraus. The digital economy: trends and prospects for avant-garde development [Tsyfrovaekonomika: trendy ta perspektyvyavanhardnohokharakterurozvytku] : URL http://www.economy.nayka.com.ua/pdf/1_2018/8.pdf.

8. Public administration in the conditions of the development of information society: textbook [Derzhavneupravlinnia umovakhrozvytkuinformatsiinohosuspilstva :navch. posib.] / N. V. Hrytsiak, L. V. Lytvynova. Ed. Ph.D. of Political Sciences, Prof. N. V. Hrytsiak. K.: K.I.C. Publishing House, 2015. P. 9. 1, p. 9.

9. On Information. The Law of Ukraine [ZakonUkrainy «Pro informatsiiu»] dated 02.10.1992, No. 2657-XII, as amended in accordance with Laws No. 2756-VI dated 02.12.2010, BVR, 2011, No. 23, Art.160. URL: http://zakon1.rada.gov.ua.

10. Regulation On the Ministry of Digital Transformation of Ukraine [Polozhennya pro MinisterstvocifrovoyitransformaciyiUkrayini],

Resolution of the Cabinet of Ministers of Ukraine dated 18.09.2019 No. 856 URL: http://zakon1.rada.gov.ua. 